Article

\title{
Soybean Agronomic Performance Does Not Change with Gyp- sum Application in a Cambisol Submitted to Water Restriction in Southern Brazil
}

\author{
Fernando Marcos Brignoli ${ }^{1}$, Luciano Colpo Gatiboni ${ }^{2}$, Gilmar Luiz Mumbach ${ }^{1}$, Douglas Luiz Grando ${ }^{3}$, Abelino An- \\ acleto de Souza Junior ${ }^{1,}{ }^{*}$, Daniel Alexandre Iochims ${ }^{1}$ \\ ${ }^{1}$ Department of Soil Science and Natural Resources, Santa Catarina State University, Lages, Santa Catarina, \\ Brazil \\ ${ }^{2}$ Department of Crop and Soil Sciences, North Carolina State University, Raleigh, North Caroline, United \\ States of America \\ ${ }^{3}$ Department of Soil, Federal University of Santa Maria, UFSM, Av. Roraima, 1000 - Camobi, Santa Maria - RS, \\ CEP 97105-900, Brazil \\ *Correspondence: abelinosji@hotmail.com
}

How to cite this paper: Brignoli, $\mathrm{F}$. M., Colpo Gatiboni, L., Luiz Mumbach, G., Luiz Grando, D., Anacleto de Souza Junior, A., \& Alexandre Iochims, D. (2021). Soybean Agronomic Performance Does Not Change with Gypsum Application in a Cambisol Submitted to Water Restriction in Southern Brazil. Open Journal of Agricultural Research, 1(1), 30-44. Retrieved from https://www.scipublications.com/journal/index.php/ojar/article/view/48

Received: June 20, 2021 Accepted: July 22, 2021 Published: July 23, 2021

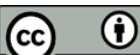

Copyright: (C) 2021 by the authors Submitted for possible open access publication under the terms and conditions of the Creative Commons Attribution (CC BY) license (http://creativecommons.org/licenses /by/4.0/).

\begin{abstract}
Water stress is a limiting factor for soybean crop development, and it may increase due to subsurface soil acidity. The use of agricultural gypsum is a way to improve the soil chemical conditions at depth and mitigate the undesirable effects caused by water restriction during drought periods. This study aimed to evaluate whether gypsum application increases soybean yield in water restriction conditions. The experiment was implemented in 2018 in a Humic Cambisol, Southern Brazil. The treatments consisted of two gypsum management procedures (with $1.4 \mathrm{Mg} \mathrm{ha}^{-1}$ and without application) associated with two water conditions (with and without water restriction). The water conditions were promoted by partially covering the soil with plastic tarpaulin sheets. Soybean was grown in the crop years 2018/19 and 2019/20 to assess root attributes and yield and were analyzed soil chemical characteristics. Water restriction reduced soybean yield by 11.4 and $36.8 \%$ in the 2018/19 and 2019/20 harvests, respectively, whereas there was no response to gypsum application. The plants' root system was not affected by the water conditions or gypsum management. It was concluded that water restriction reduces soybean yield, and agricultural gypsum does not mitigate such loss under the evaluated conditions, even though it positively changes some soil chemical parameters.
\end{abstract}

Keywords: Water stress, Acid soil, Humic Cambisol, Glycine max

\section{Introduction}

Water stress, which is caused by decreased water potential in the soil, is the main abiotic limiting factor in annual crops. Water deficit promotes changes in plants' biochemical and physiological processes, such as photosynthesis, respiration, and nutrient absorption [1]. The magnitude of the losses caused by water deficiency during the crop cycle also depends on the stress, the phenological stage affected, the cultivar, and management strategies implemented to mitigate impacts [2]. Among the main dryland crops, soybean (Glycine max) is severely affected by drought events due to the plant's high water demand during its cycle [3].

By adopting the no-tillage system (NT), higher soil moisture stability is observed due to crop residues present on the soil surface [4]. However, only the physical protection of the soil surface does not ensure yield stability in water-deficit periods. Another relevant characteristic of soils conducted under NT is the correction of surface acidity [5]. Surface application without limestone incorporation can hinder subsurface acidity correction; 
therefore, it is necessary to condition the soil at depth to reduce the impacts of such chemical gradient [6].

Agricultural gypsum $\left(\mathrm{CaSO}_{4} \cdot 2 \mathrm{H}_{2} \mathrm{O}\right)$, a by-product of phosphate fertilizer manufacture, can be an efficacious alternative to reduce susceptibility to water scarcity periods and mitigate toxic aluminum $\left(\mathrm{Al}^{3+}\right)$ effects for plants [7]. From a chemical point of view, gypsum does not generate negative electrical charges in the soil, which allows greater calcium (Ca) migration at depth as opposed to limestone [8]. In addition to Ca, gypsum provides sulfur $(\mathrm{S})$ in the form of sulfate $\left(\mathrm{SO}_{4}{ }^{2-}\right)[9,10]$, which can decrease $\mathrm{Al}$ toxicity by the formation of an ionic pair $\left(\mathrm{AlSO}_{4}\right)$.

The beneficial effects of gypsum in water stress conditions are directly related to subsurface edaphic environment improvement. Calcium supply and, consequently, Al toxicity reduction favor root growth at depth [7], reaching soil regions with greater water availability [3]. Considering field research conducted in Brazil, Tiecher et al., 2018 and Pias et al., 2020 reported that gypsum has good technical response in the presence of toxic $\mathrm{Al}$ concentrations in the subsurface and water restriction. Soybean crops are more likely to have positive responses to gypsum management when they coincide with water stress periods in acidic subsurface soils $[13,14]$.

However, most of the information reported in the literature on this subject comes from studies conducted on Oxisols [12]. Therefore, there is a need for research to cover other soil classes, making it possible to extend recommendations and confirm the response patterns shown in the literature to other edaphoclimatic conditions.

This study hypothesizes that the use of agricultural gypsum increases soybean yield in acidic soil during water restriction periods. In this context, the study aimed to evaluate the chemical changes in Cambisol after agricultural gypsum application and its effect on soybean yield under two water conditions.

\section{Material and Methods}

The experiment was conducted at the Experimental Farm of the for Agroveterinary Sciences Center of Santa Catarina State University (CAV/UDESC), in the municipality of Lages - Santa Catarina (latitude $27^{\circ} 44^{\prime} 54.11^{\prime \prime} \mathrm{S}$ and longitude 50 $05^{\prime} 08.09^{\prime \prime}$ W, at 884 meters of altitude), Southern Brazil. According to the Köppen classification [15], the local climate is classified as $C f b$ type (humid mesothermal, and mild summers).

The soil is classified as a Cambissolo Húmico/Humic Cambisol [16,17], showing good to moderate drainage and the following characteristics, obtained in the $0-20 \mathrm{~cm}$ layer before installation of the experiment: clay content: $28 \%$; $\mathrm{pH}-\mathrm{H}_{2} \mathrm{O}: 4.6$; SMP index: 4.9 ; soil organic matter content (SOM): 5.1\%; Available phosphorus (P) (by Mehlich 1): $7.9 \mathrm{mg} \mathrm{dm}$ 3; Exchangeable potassium (K): $186.8 \mathrm{mg} \mathrm{dm}^{-3}$ (by Mehlich 1); Exchangeable aluminum (Al): $2.9 \mathrm{cmol}_{\mathrm{c} \mathrm{dm}} \mathrm{dm}^{-3}$ Ca: $5.6 \mathrm{cmol}_{\mathrm{c} \mathrm{dm}}{ }^{-3}$; Magnesium (Mg): $3.2 \mathrm{cmolc} \mathrm{dm}^{-3}$; Potential acidity ( $\mathrm{H}+\mathrm{Al}): 15.6 \mathrm{cmol}_{\mathrm{c}} \mathrm{dm}^{-3}$; sum of bases: $9.3 \mathrm{cmol}_{\mathrm{c}} \mathrm{dm}^{-3}$; CEC effective and CEC $\mathrm{pH} 7.0: 12.2$ and $24.8 \mathrm{cmolc}_{\mathrm{cm}}^{-3}$, respectively.

In 2015, soil acidity was corrected with limestone incorporation in the $0-20 \mathrm{~cm}$ layer, aiming to raise $\mathrm{pH}-\mathrm{H}_{2} \mathrm{O}$ to 5.5 by using dolomitic limestone with $90 \%$ total relative neutralizing power (TRNP) and $29 \%$ and $19 \% \mathrm{CaO}$ and $\mathrm{MgO}$, respectively. Subsequently, $\mathrm{P}$ availability was corrected in the soil by applying $50 \mathrm{~kg} \mathrm{ha}^{-1}$ of $\mathrm{P}_{2} \mathrm{O}_{5}$, in the form of triple superphosphate. Sequential crops of beans, wheat, corn, and wheat were performed in 2015/2016, 2016, 2016-2017, and 2017, respectively, with each crop receiving maintenance fertilizer for P and K as recommended by CQFS-RS/SC (2016). After the last crop, the area was kept fallow. 
In October 2018, the experiment was installed under a completely randomized design, in a $2 \times 2$ factorial scheme and three replications. Two gypsum management procedures were tested, with and without its application, and two water conditions, absence, and presence of water restriction in the soil. Gypsum was characterized and showed 21\% $\mathrm{Ca}, 16 \%$ sulfur $(\mathrm{S})$, and $0.9 \%$ phosphorus $\left(\mathrm{P}_{2} \mathrm{O}_{5}\right)$. The gypsum rate $(\mathrm{GR})$ was calculated according to the equation [GR $\left(\mathrm{Mg} \mathrm{ha}^{-1}\right)=50 x$ clay content $\left.(\%)\right]$ [18], resulting in $1.4 \mathrm{Mg}$ ha1. Gypsum was applied manually and homogeneously to the soil surface.

In November 2018, soil water control systems were implemented, using translucent plastic tarpaulin sheets arranged in different ways in the space between the sowing rows, remaining there throughout the study period (Figure 1). For treatments without water restriction, the tarpaulin sheets were placed in the form of an inverse gutter (Figure 1-A and 1-C), allowing the water from rainfall to enter and maintaining the other similar environmental conditions. In treatments with water restriction, the tarpaulins sheets were placed on the soil surface, forming a gutter to exclude part of rainfall water (Figures 1-B and 1-D). Such installation aimed to limit rainwater entry to $60 \%$ in the water restriction condition. Around the plots, a plastic retainer was installed. It was buried in the ground to spread and prevent runoff water from the environment adjacent to the experiment from entering.

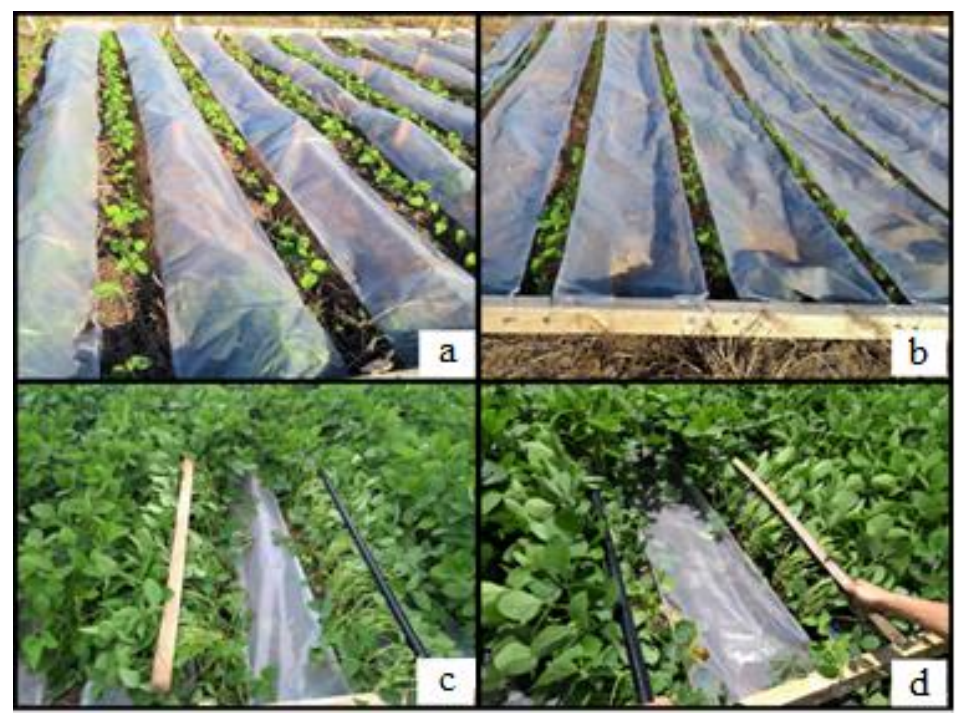

Figure 1. Layout of the soil's water-condition control system. Images A and C illustrates the system for maintaining rainwater in the plot, whereas images B and D show the system used to exclude part of the rainwater.

Soybean was grown in the 2018/19 and 2019/20 harvests, using the Nidera 5909 RR cultivar. The seeds were arranged with row spacing of $0.5 \mathrm{~m}$ and plant density of 300 thousand seeds ha-1. Before sowing, the seeds were treated with a sodium-molybdate and cobalt-sulfate solution to provide molybdenum and cobalt, respectively. Also, they were treated with peat inoculant, aiming to optimize the symbiosis with $\mathrm{N}$-fixing bacteria. Fertilizer was applied on the surface according to the maintenance criteria for $\mathrm{P}$ and $\mathrm{K}$, with the expected yield of $4.0 \mathrm{Mg} \mathrm{ha}^{-1}$ [9], and using triple superphosphate and potassium chloride as sources, respectively. Phytosanitary management of weeds, pests, and diseases followed the technical criteria for soybean crops. Grain yield was obtained by harvesting an area of $1.5 \mathrm{~m}^{2} \mathrm{plot}^{-1}$. After harvesting, the seeds were dried in a forced ventilation oven at $60^{\circ} \mathrm{C}$ until a constant weight was achieved, with subsequent adjustment for grain moisture of $13 \%$. 
During the R2 phenological stage, in the 2018/19 harvest, roots were sampled in four soil layers $(0-10,10-20,20-30$, and $30-40 \mathrm{~cm})$, using a cylindrical auger of internal diameter $4.5 \mathrm{~cm}$. The samples were removed in the spacing between the plot central rows, with each treatment represented by one repetition. Subsequently, the roots were cleaned by water jets and a set of sieves of minimum mesh $0.5 \mathrm{~mm}$ to remove soil and other impurities. The root material was placed in ethyl-alcohol solution and stored under cooling conditions at $4{ }^{\circ} \mathrm{C}$. The surface area, volume, and root length density were determined using the WinRHIZO software, and dry mass was obtained after oven-drying at $60{ }^{\circ} \mathrm{C}$.

In May 2019, soil collection was performed in layers 0-10, 10-20, 20-30, and $30-40 \mathrm{~cm}$, using an auger. The samples were oven-dried at $60^{\circ} \mathrm{C}$, sieved through a $2 \mathrm{~mm}$ mesh sieve and the following chemical attributes were subsequently evaluated according to the methodologies proposed by Tedesco et al. (1995): $\mathrm{pH}-\mathrm{H}_{2} \mathrm{O}$ (1:1 soil-water ratio), available $\mathrm{P}$ and exchangeable K, extracted by Mehlich 1 and determined by molecular absorption spectrophotometry [20] and flame photometry, respectively. Calcium, $\mathrm{Mg}$ and $\mathrm{Al}$ were extracted by $1 \mathrm{~mol} \mathrm{~L}^{-1} \mathrm{KCl}$, with $\mathrm{Ca}$ and $\mathrm{Mg}$ being determined by atomic absorption spectrophotometry and $\mathrm{Al}$ by titration with $0.0125 \mathrm{M} \mathrm{NaOH}$ solution. Soil organic matter content was obtained by the sulfochromic solution oxidation method, and $\mathrm{S}^{-\mathrm{SO}_{4}{ }^{2-}}$ was extracted by $\mathrm{Ca}\left(\mathrm{H}_{2} \mathrm{PO}_{4}\right)_{2} \cdot \mathrm{H}_{2} \mathrm{O}$ and determined by turbidimetry. Potential acidity was estimated by correlation with the obtained $\mathrm{pH}$ value in TSM solution [21]. To calculate $\mathrm{CEC}_{\text {effective, alumi- }}$ num saturation $(\mathrm{m} \%), \mathrm{CEC} \mathrm{pH} 7.0$, and bases saturation $(\mathrm{V} \%)$, the equations provided by CQFS-RS/SC (2016) were used.

To evaluate the effectiveness of the rainwater exclusion system in the experimental plots, soil was collected from the 0-10 and 10-20 cm layers during the different phenological stages of soybean. Sampling was performed using an auger, and the soil was packed in plastic bags to prevent moisture loss. Gravimetric moisture was determined, and soil density and volumetric moisture were obtained from collections using soil sample rings. The permanent wilting point and field capacity were calculated based on the voltages of 1,500 and $10 \mathrm{kPa}$, respectively, according to the pedotransfer functions presented by [22], which take into account the texture and SOM content.

Shapiro-Wilk test was applied to the data obtained during the experiment to evaluate normality. Subsequently, analysis of variance (ANOVA) was performed, and the means were compared by the Tukey test at a 5\% significance level. The analyses were performed by the SISVAR 5.6 statistical software [23], and the graphics were designed using the SigmaPlot 12.5 software.

\section{Results and Discussion}

\subsection{Performance of the water exclusion system}

There were significant differences in moisture content between the water conditions implemented in the two years evaluated (Figure 2). In the 2018/19 harvest, volumetric moisture without water restriction was $35.8,7.4,8.8$, and $15.6 \%$ higher than that with the restriction condition, considering the emergence, vegetative, flowering, and pod-filling stages, respectively. However, when considering the previously mentioned stages for the 2019/20 harvest, it was found that volumetric moisture in the condition without water restriction was 9.0, 5.2, 12.6, and 9.3\% higher than with water restriction, respectively.

The field capacity and permanent wilting point estimated values for the soil were 0.53 and $0.29 \mathrm{~m}^{3} \mathrm{~m}^{-3}$, respectively, which are within the range found in studies for the state of Santa Catarina $[22,24]$. It was observed that in both years, treatment with water restriction approached and remained partially below permanent wilting point (Figures $2 \mathrm{a}$ and b), with the 2019/20 agricultural year being more affected since its treatment without 
water restriction was compromised. Regardless of the evaluated period, the 10-20 cm layer (Figure 2c) showed higher moisture compared to the surface layer, reinforcing that the evapotranspiration and drying process begins in the soil topmost regions.
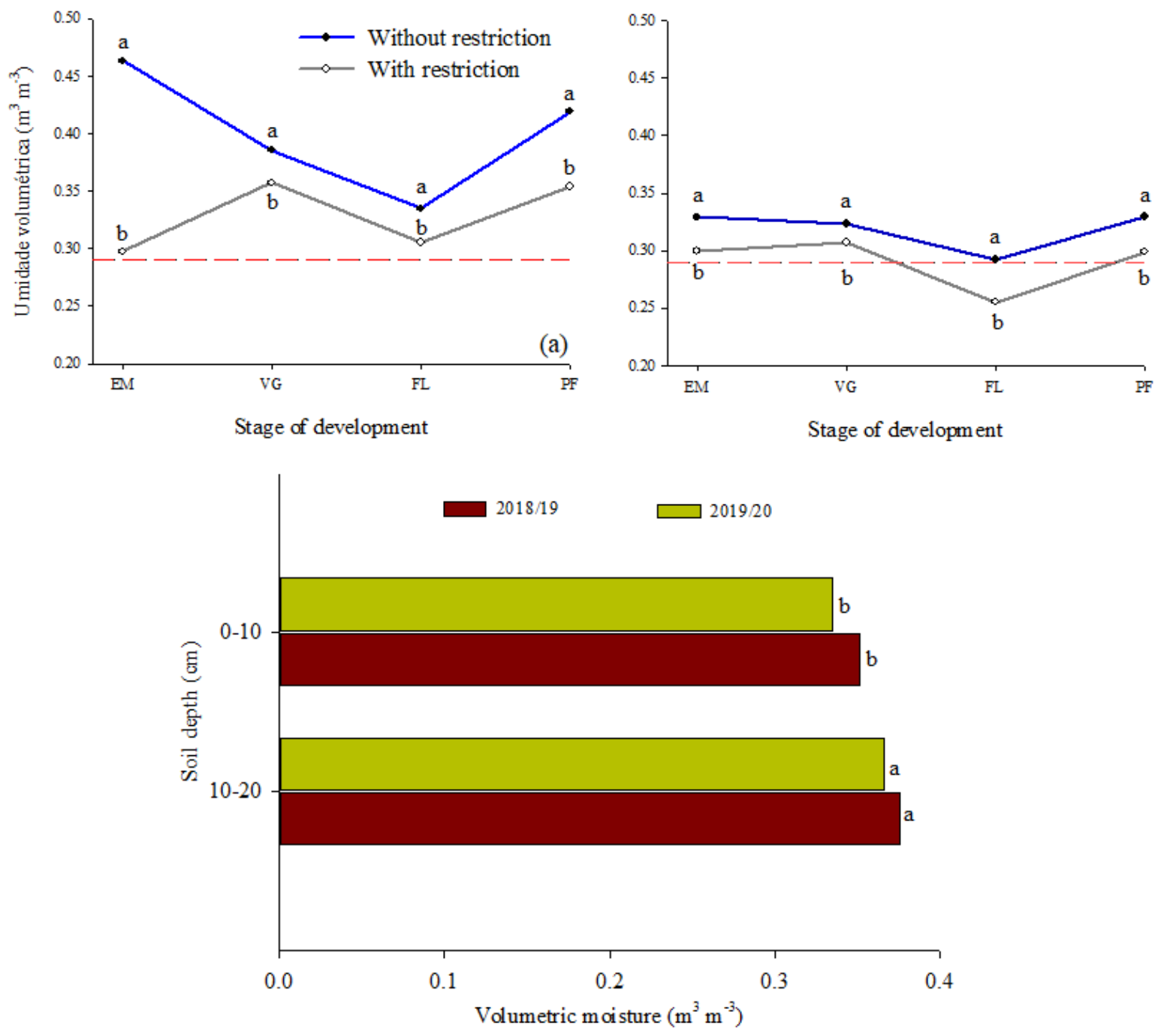

Figure 2. The soil volumetric moisture $\left(\mathrm{m}^{3} \mathrm{~m}^{-3}\right)$ at different phenological stages of the soybean crop in the agricultural years 2018/19 (a) and 2019/20 (b). The soil volumetric moisture in the 0-10 and 10$20 \mathrm{~cm}$ layers during two growing periods (c). Means followed by different letters at the same phenological stage and between layers in each year show a significant difference using the Tukey test $(\mathrm{p}<0.05)$. The red dashed line represents the soil volumetric moisture at the permanent wilting point (PWP). EM: Emergence; VG: Vegetative; FL: Flowering; PD: Pod-filling.

Some physical-chemical factors, such as SOM content, are strongly associated with water availability in the soil [22]. Because of the high specific surface of SOM concerning other minerals, it can contribute significantly to maintaining adequate soil water conditions [25] and improving the stability of soil aggregates in NT [26]. However, in this study, the high SOM content observed on the soil surface $(0-20 \mathrm{~cm})$ may not have been sufficient to assist in maintaining soil moisture due to the magnitude of the restriction promoted. The presence of 2:1 minerals in partially developed soils, such as Cambisols, is also a factor that improves water retention due to the expansion capacity of these minerals [27]. 
Because moisture measurements were performed by periodic sampling, the values may not represent the actual levels due to the temporal variability of soil moisture within each cropping stage, since a constant measurement is recommended. However, when analyzing the total volume precipitated in the agricultural years 2018/19 (655 $\mathrm{mm}$ ) and $2019 / 20(505 \mathrm{~mm}$ ) (Figure 3) and considering the partial entry of $40 \%$ of water in treatments with water restriction, the total amounts of 262 and $202 \mathrm{~mm}$ are obtained, respectively. These values are lower than the water quantity necessary for the normal development of soybeans [28].

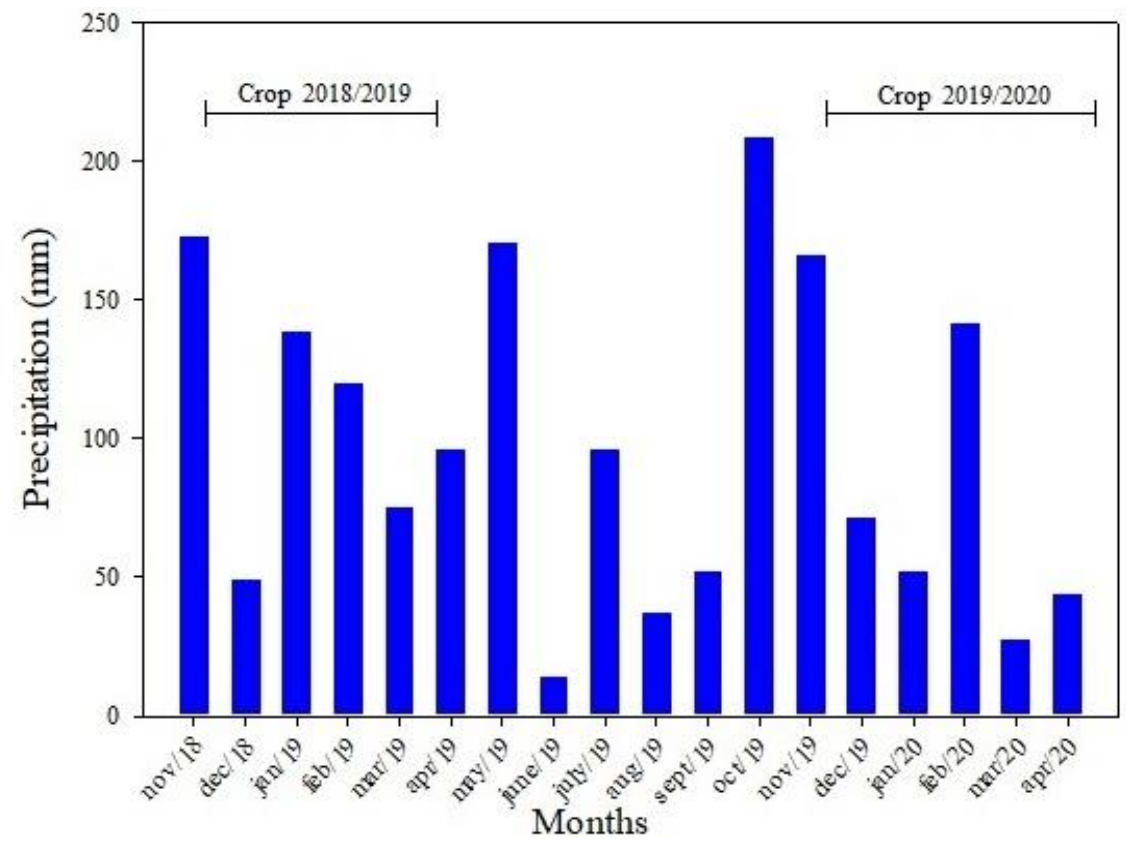

Figure 3. Monthly rainfall during the first (2018/19) and second (2019/20) soybean crops.

\subsection{Soil chemical characteristics}

Gypsum application had low influence on acidity-related soil attributes, while water conditions did not show significant effects (Table 1). Agricultural gypsum reduced Al content in the mean for the $0-40 \mathrm{~cm}$ layer and decreased $\mathrm{Al}$ saturation by approximately $55 \%$ in the $10-20 \mathrm{~cm}$ layer (Table 1). Considering the soil layers sampled regardless of gypsum management and water conditions, when deeper areas were evaluated, reduced values for $\mathrm{pH}-\mathrm{H}_{2} \mathrm{O}, \mathrm{V} \%$, and $\mathrm{SOM}$ and increased values for $\mathrm{H}+\mathrm{Al}, \mathrm{Al}$, and $\mathrm{m} \%$ were observed.

The lack of effects from agricultural gypsum on $\mathrm{pH}$ is related to its inability to generate electrical charges in the soil, unlike limestone. However, in some situations, small variations are observed for this parameter. They are caused by exchange reactions between $\mathrm{Ca}$ and $\mathrm{Al}$ on the surface of colloids, allowing the latter to generate $\mathrm{H}^{+}$ions by the hydrolysis reactions in the solution [10], increasing acidity or raising $\mathrm{pH}$ due to the effect of $\mathrm{SO}_{4}{ }^{2-}$ on displacing $\mathrm{OH}^{-}$ions from colloids to the solution [13]. The non-change in the number of negative charges accompanied by the supply of Ca may, as observed in this study, reduce $\mathrm{Al}$ saturation by the displacement of the toxic element to the solution, caused by the divalent ion $[6,13]$. Hence, $\mathrm{Al}$ may precipitate as an $\mathrm{AlSO}_{4}{ }^{+}$ionic pair $[8,10]$. 
Table 1. Changes in soil chemical attributes related to soil acidity and organic matter content due to the management of agricultural gypsum and soil water condition in four layers evaluated in a Cambisol.

\begin{tabular}{|c|c|c|c|c|c|}
\hline Soil depth $(\mathrm{cm})$ & \multicolumn{5}{|c|}{ Soil chemical properties } \\
\hline \multicolumn{6}{|c|}{$\mathrm{pH}-\mathrm{H}_{2} \mathrm{O}$} \\
\hline & \multicolumn{2}{|c|}{----Gypsum---- } & \multicolumn{2}{|c|}{----Water restriction---- } & \multirow[b]{2}{*}{ Mean } \\
\hline & without & with & without & with & \\
\hline $0-10$ & $5.56^{\mathrm{ns}}$ & 5.58 & $5.51^{\mathrm{ns}}$ & 5.63 & $5.57 \mathrm{a}$ \\
\hline $10-20$ & $5.02^{\mathrm{ns}}$ & 5.08 & $5.01^{\mathrm{ns}}$ & 5.09 & $5.05 \mathrm{~b}$ \\
\hline $20-30$ & $4.35^{\mathrm{ns}}$ & 4.37 & $4.36^{\mathrm{ns}}$ & 4.36 & $4.36 \mathrm{c}$ \\
\hline $30-40$ & $4.21^{\mathrm{ns}}$ & 4.25 & $4.25^{\mathrm{ns}}$ & 4.20 & $4.23 \mathrm{c}$ \\
\hline Mean & $4.79 \mathrm{~ns}$ & 4.82 & $4.80^{\mathrm{ns}}$ & 4.80 & \\
\hline CV (\%) & \multicolumn{4}{|c|}{5.25} & \\
\hline \multicolumn{6}{|c|}{$\mathrm{H}+\mathrm{Al}\left(\mathrm{cmol}_{\mathrm{c}} \mathrm{dm}^{-3}\right)$} \\
\hline $0-10$ & $6.69^{\text {ns }}$ & 7.27 & $7.88^{\mathrm{ns}}$ & 6.38 & $7.13 \mathrm{~d}$ \\
\hline $10-20$ & $15.10^{\mathrm{ns}}$ & 12.89 & $14.65^{\mathrm{ns}}$ & 13.35 & $14.00 \mathrm{c}$ \\
\hline $20-30$ & $28.40^{\mathrm{ns}}$ & 27.92 & $28.58^{\mathrm{ns}}$ & 27.81 & $28.19 b$ \\
\hline $30-40$ & $34.40^{\mathrm{ns}}$ & 35.88 & $36.55^{\mathrm{ns}}$ & 33.74 & $35.14 \mathrm{a}$ \\
\hline Mean & $21.24^{\mathrm{ns}}$ & 20.99 & $21.91^{\mathrm{ns}}$ & 20.32 & \\
\hline CV (\%) & & & 19.98 & & \\
\hline \multicolumn{6}{|c|}{$\mathrm{Al}\left(\mathrm{cmol}_{\mathrm{c}} \mathrm{dm}^{-3}\right)$} \\
\hline $0-10$ & $0.40^{\mathrm{ns}}$ & 0.19 & $0.25^{\mathrm{ns}}$ & 0.35 & $0.30 \mathrm{~d}$ \\
\hline $10-20$ & $2.20^{\mathrm{ns}}$ & 1.22 & $1.69^{\mathrm{ns}}$ & 1.80 & $1.75 \mathrm{c}$ \\
\hline $20-30$ & $5.70^{\mathrm{ns}}$ & 5.76 & $5.03^{\mathrm{ns}}$ & 5.88 & $5.45 \mathrm{~b}$ \\
\hline $30-40$ & $7.80^{\mathrm{ns}}$ & 7.23 & $7.35^{\mathrm{ns}}$ & 7.69 & $7.52 \mathrm{a}$ \\
\hline Mean & $4.06^{*}$ & 3.45 & $3.58^{\mathrm{ns}}$ & 3.93 & \\
\hline CV (\%) & & & 27.84 & & \\
\hline \multicolumn{6}{|c|}{$\mathrm{m} \%(\%)$} \\
\hline $0-10$ & $2.39^{\text {ns }}$ & 1.20 & $1.57^{\mathrm{ns}}$ & 2.02 & $1.79 \mathrm{~d}$ \\
\hline $10-20$ & $17.29 \mathrm{~A}$ & $7.77 \mathrm{~B}$ & $11.25^{\mathrm{ns}}$ & 13.81 & $12.53 \mathrm{c}$ \\
\hline $20-30$ & $52.90^{\mathrm{ns}}$ & 47.03 & $46.36^{\mathrm{ns}}$ & 53.57 & $49.97 \mathrm{~b}$ \\
\hline $30-40$ & $72.50^{\mathrm{ns}}$ & 66.31 & $65.74^{\mathrm{ns}}$ & 73.12 & $69.43 a$ \\
\hline Mean & $36.28^{*}$ & 30.57 & $31.23^{\mathrm{ns}}$ & 35.63 & \\
\hline CV $(\%)$ & & & 24.37 & & \\
\hline \multicolumn{6}{|c|}{$\mathrm{V} \%(\%)$} \\
\hline $0-10$ & $70.39^{\text {ns }}$ & $6 ., 25$ & $66.78^{\text {ns }}$ & 72.87 & $69.82 \mathrm{a}$ \\
\hline $10-20$ & $42.56^{\mathrm{ns}}$ & 53.27 & $48.93^{\mathrm{ns}}$ & 46.90 & $47.91 \mathrm{~b}$ \\
\hline $20-30$ & $15.10^{\mathrm{ns}}$ & 17.46 & $17.32^{\mathrm{ns}}$ & 15.25 & $16.28 \mathrm{c}$ \\
\hline $30-40$ & $7.84^{\mathrm{ns}}$ & 9.70 & $9.79^{\mathrm{ns}}$ & 7.75 & $8.77 \mathrm{~d}$ \\
\hline Mean & $33.97^{\mathrm{ns}}$ & 33.42 & $35.70^{\mathrm{ns}}$ & 35.69 & \\
\hline CV (\%) & & & 18.07 & & \\
\hline \multicolumn{6}{|c|}{ SOM (\%) } \\
\hline $0-10$ & $5.38^{\mathrm{ns}}$ & 5.22 & $5.38^{\mathrm{ns}}$ & 5.22 & $5.30 \mathrm{a}$ \\
\hline $10-20$ & $4.20^{\mathrm{ns}}$ & 4.56 & $4.35^{\mathrm{ns}}$ & 4.45 & $4.40 \mathrm{~b}$ \\
\hline $20-30$ & $3.00^{\mathrm{ns}}$ & 3.20 & $3.10^{\mathrm{ns}}$ & 3.10 & $3.10 \mathrm{c}$ \\
\hline $30-40$ & $2.20^{\mathrm{ns}}$ & 2.58 & $2.55^{\mathrm{ns}}$ & 2.27 & $2.41 \mathrm{~d}$ \\
\hline Mean & $3.90^{\mathrm{ns}}$ & 3.71 & $3.85^{\mathrm{ns}}$ & 3.76 & \\
\hline CV (\%) & & & 10.68 & & \\
\hline
\end{tabular}


Means followed by different lower-case letters within the column and different capital letters in the line, to the two factors, differ statistically $(\mathrm{p}<0.05)$. $\mathrm{m} \%$ : aluminum saturation. $\mathrm{V} \%$ : base saturation. SOM: soil organic matter. * significant by the Tukey test $(\mathrm{p}<0.05)$; ns: non-significant. CV: Coefficient of variation.

The changes observed along the soil profile, without any dependence on the factors evaluated in this study, agree with reports in the literature. The higher SOM content and the presence of higher $\mathrm{pH}$ and higher $\mathrm{V} \%$ in the surface layers are due to the non-disturbance of the soil and the application of soil conditioners in the surface layers [29].

There were changes in nutrient availability in the soil due to gypsum management and soil water condition (Table 2). Agricultural gypsum increased the availability of $\mathrm{SO}_{4}{ }^{2-}$ (10-40 cm layer), Ca (10-20 cm layer), and P (0-10 cm layer), but did not change the exchangeable $\mathrm{K}$ and $\mathrm{Mg}$ contents. Interestingly, in the $0-10 \mathrm{~cm}$ layer, $\mathrm{K}$ was higher in the condition without water deficiency, while the other nutrients were not affected by the water condition. By considering the mean effects on the soil profile analyzed, there was a reduction in the labile content of all nutrients, except for $\mathrm{SO}_{4}{ }^{2-}$, whose content was higher in the 10-40 cm layers, as compared to that in the surface layer.

Agricultural gypsum has high amounts of $\mathrm{Ca}$ and $\mathrm{SO}_{4}{ }^{2-}$ in its constitution, which justifies their increase in the soil [6]. Regardless of gypsum management, Ca levels were similar in the treatments, especially in the uppermost layer, in which the high values (CQFSRS/SC, 2016) may reflect the residual liming effect [30,31].

Phosphorus increase resulting from gypsum application can be attributed to the presence of $\mathrm{SO}_{4}{ }^{2-}$, which, even with a low decrease in $\mathrm{P}$ adsorption, causes a lability increase [32]. Also, gypsum is a residue from the manufacture of phosphate fertilizers, and, consequently, the presence of small $\mathrm{P}$ amounts in the product is common (CQFS-RS/SC, 2016). The high adsorption capacity of $\mathrm{P}$ with clay particles, associated with low mobility in the soil, provides its greater accumulation on the surface [33]. The non-change in $\mathrm{K}$ and $\mathrm{Mg}$ values is justified by high soil CEC, which limits these cations' displacement in the soil profile, contrary to what is commonly observed in soils with less acidity buffering. Applications of high gypsum rates and/or in soils with low CEC can displace $\mathrm{K}$ and $\mathrm{Mg}$ from the surface of loads and, consequently, result in vertical displacement [11].

Increased $\mathrm{S}_{-} \mathrm{SO}_{4}{ }^{2-}$ at depth is due to the association of some factors, such as the limited ability to compete with phosphate for adsorption sites [32] and the formation of ionic pairs with $\mathrm{Ca}$ and $\mathrm{Al}$ [30]. Many studies have observed that a reduction in $\mathrm{SO}_{4}{ }^{2-}$ availability at depth occurs again in regions of the soil where there is a low P concentration [34]. However, in this study, $\mathrm{S}_{-} \mathrm{SO}_{4}{ }^{2-}$ mobility may be related to $\mathrm{CaSO}_{4}$ formation when Ca increases in the 10-20 $\mathrm{cm}$ layer or by $\mathrm{AlSO}_{4}{ }^{+}$formation.

Potassium content was lower with the presence of water restriction in the soil. This effect was pronounced in the $0-10 \mathrm{~cm}$ layer and can be attributed to the combination of mineralogical and water factors. Many soils in the Southern Brazil have expressive amounts of 2:1 clay minerals that lend the ability to fix $\mathrm{K}$ in the interlayers [35]. This effect is even more pronounced in drier soil conditions, due to the lesser amount of water that migrates inside the minerals, reducing K expansion and release capacity [36], thus resulting in smaller extracted quantities. It is assumed that this behavior may have occurred in this soil, given the lower overall soil moisture in the topmost layer (Figure 2c). 
Table 2. Changes in soil nutrient availability as a function of agricultural gypsum management and the soil water conditions in four evaluated layers of a Cambisol.

\begin{tabular}{|c|c|c|c|c|c|}
\hline Soil depth $(\mathrm{cm})$ & \multicolumn{5}{|c|}{ Soil chemical properties } \\
\hline \multicolumn{6}{|c|}{$\mathrm{S}-\mathrm{SO}_{4}{ }^{2-}\left(\mathrm{mg} \mathrm{dm}^{-3}\right)$} \\
\hline & \multicolumn{2}{|c|}{----Gypsum---- } & \multicolumn{2}{|c|}{----Water restriction---- } & \\
\hline & without & With & Without & With & Mean \\
\hline $0-10$ & $24.41^{\mathrm{ns}}$ & 29.79 & $26.08^{\mathrm{ns}}$ & 28.12 & $27.10 \mathrm{~b}$ \\
\hline $10-20$ & $27.70 \mathrm{~B}$ & $46.39 \mathrm{~A}$ & $33.14^{\mathrm{ns}}$ & 40.95 & $37.05 \mathrm{a}$ \\
\hline $20-30$ & $31.39 \mathrm{~B}$ & $44.73 \mathrm{~A}$ & $39.60^{\mathrm{ns}}$ & 36.53 & $38.06 \mathrm{a}$ \\
\hline $30-40$ & $28.39 \mathrm{~B}$ & $45.01 \mathrm{~A}$ & $33.21^{\mathrm{ns}}$ & 40.19 & $36.70 \mathrm{a}$ \\
\hline Mean & 27.97 & $41.48^{*}$ & $3301^{\mathrm{ns}}$ & 36.45 & \\
\hline $\mathrm{CV}(\%)$ & \multicolumn{4}{|c|}{24.40} & \\
\hline \multicolumn{6}{|c|}{$\mathrm{K}\left(\mathrm{mg} \mathrm{dm}^{-3}\right)$} \\
\hline $0-10$ & $249.20^{\mathrm{ns}}$ & 233.50 & $276.18 \mathrm{~A}$ & $206.50 \mathrm{~B}$ & $241.34 \mathrm{a}$ \\
\hline $10-20$ & $127.16^{\mathrm{ns}}$ & 132.12 & $139.80^{\text {ns }}$ & 119.55 & $129.65 b$ \\
\hline $20-30$ & $91.00^{\mathrm{ns}}$ & 95.15 & $91.41^{\mathrm{ns}}$ & 94.44 & $93.00 \mathrm{bc}$ \\
\hline $30-40$ & $90.35^{\mathrm{ns}}$ & 81.55 & $85.25^{\mathrm{ns}}$ & 86.59 & $85.93 \mathrm{c}$ \\
\hline Mean & $139.42^{\text {ns }}$ & 135.58 & $148.16^{*}$ & 126.77 & \\
\hline $\mathrm{CV}(\%)$ & \multicolumn{4}{|c|}{27.70} & \\
\hline \multicolumn{6}{|c|}{$\mathrm{Ca}\left(\mathrm{cmolc}_{\mathrm{dm}}{ }^{-3}\right)$} \\
\hline $0-10$ & $10.09^{n s}$ & 10.28 & $9.60^{\mathrm{ns}}$ & 10.77 & $10.18 \mathrm{a}$ \\
\hline $10-20$ & $6.30 \mathrm{~B}$ & $8.34 \mathrm{~A}$ & $8.05^{\mathrm{ns}}$ & 6.59 & $7.32 \mathrm{~b}$ \\
\hline $20-30$ & $2.50^{\mathrm{ns}}$ & 2.87 & $2.96^{\mathrm{ns}}$ & 2.40 & $2.68 \mathrm{c}$ \\
\hline $30-40$ & $1.35^{\mathrm{ns}}$ & 1.78 & $1.85^{\mathrm{ns}}$ & 1.28 & $1.56 \mathrm{c}$ \\
\hline Mean & 5.06 & $5.82^{*}$ & $5.62^{\mathrm{ns}}$ & 5.26 & \\
\hline CV (\%) & \multicolumn{4}{|c|}{21.74} & \\
\hline \multicolumn{6}{|c|}{$\mathrm{Mg}\left(\mathrm{cmol}_{\mathrm{c}} \mathrm{dm}^{-3}\right)$} \\
\hline $0-10$ & $5.72^{\mathrm{ns}}$ & 5.36 & $5.19 \mathrm{~A}$ & $5.88 \mathrm{~A}$ & $5.54 \mathrm{a}$ \\
\hline $10-20$ & $4.61^{\mathrm{ns}}$ & 5.16 & $5.01 \mathrm{~A}$ & $4.76 \mathrm{~A}$ & $4.88 \mathrm{a}$ \\
\hline $20-30$ & $2.34^{\mathrm{ns}}$ & 2.63 & $2.59 \mathrm{~A}$ & $2.38 \mathrm{~A}$ & $2.48 \mathrm{~b}$ \\
\hline $30-40$ & $1.36^{\mathrm{ns}}$ & 1.76 & $1.82 \mathrm{~A}$ & $1.30 \mathrm{~A}$ & $1.56 \mathrm{c}$ \\
\hline Mean & $3.51^{\mathrm{ns}}$ & 3.72 & $3.66^{\mathrm{ns}}$ & 3.58 & \\
\hline CV (\%) & \multicolumn{4}{|c|}{18.81} & \\
\hline \multicolumn{6}{|c|}{$\mathrm{P}\left(\mathrm{mg} \mathrm{dm}^{-3}\right)$} \\
\hline $0-10$ & $18.72 \mathrm{~B}$ & $22.61 \mathrm{~A}$ & $20.99^{n s}$ & 20.33 & $20.66 a$ \\
\hline $10-20$ & $6.34^{\mathrm{ns}}$ & 6.76 & $8.18^{\mathrm{ns}}$ & 4.92 & $6.55 \mathrm{~b}$ \\
\hline $20-30$ & $4.24^{\mathrm{ns}}$ & 6.22 & $5.59^{\mathrm{ns}}$ & 4.87 & $5.23 \mathrm{~b}$ \\
\hline $30-40$ & $2.76^{\mathrm{ns}}$ & 3.94 & $3.64^{\mathrm{ns}}$ & 3.07 & $3.35 \mathrm{~b}$ \\
\hline Mean & 8.01 & $9.88^{*}$ & $9.60^{\mathrm{ns}}$ & 8.30 & \\
\hline CV (\%) & & & 36.67 & & \\
\hline
\end{tabular}

Means followed by different lower-case letters within the column and different capital letters in the line, to the two factors, differ statistically $(\mathrm{p}<0.05)$. * significant by the Tukey test $(\mathrm{p}<0.05)$; ns: not significant. CV: Coefficient of variation.

\subsection{Agronomic response of soybeans}

Soybean yield was only affected by the soil water condition, with no effects from gypsum or interaction between the observed factors (Figure 4). In the 2018/19, 2019/20, and cumulative harvests, soybean yield was $11.4,36.8$, and $20.0 \%$ higher in the condition without water restriction, respectively. Generally, the yield was severely affected in the 
2019/20 agricultural year, being lower than the national average of $3.2 \mathrm{Mg} \mathrm{ha}^{-1}$ in the 2018/19 harvest [37], even in the treatment without water restriction, caused by a drought period in the first months of the year.

The losses caused by water deficiency to the growth and yield of plants are well known [38] and routinely experienced by farmers. The magnitude of losses caused by water stress is also directly related to the duration of such conditions [39].
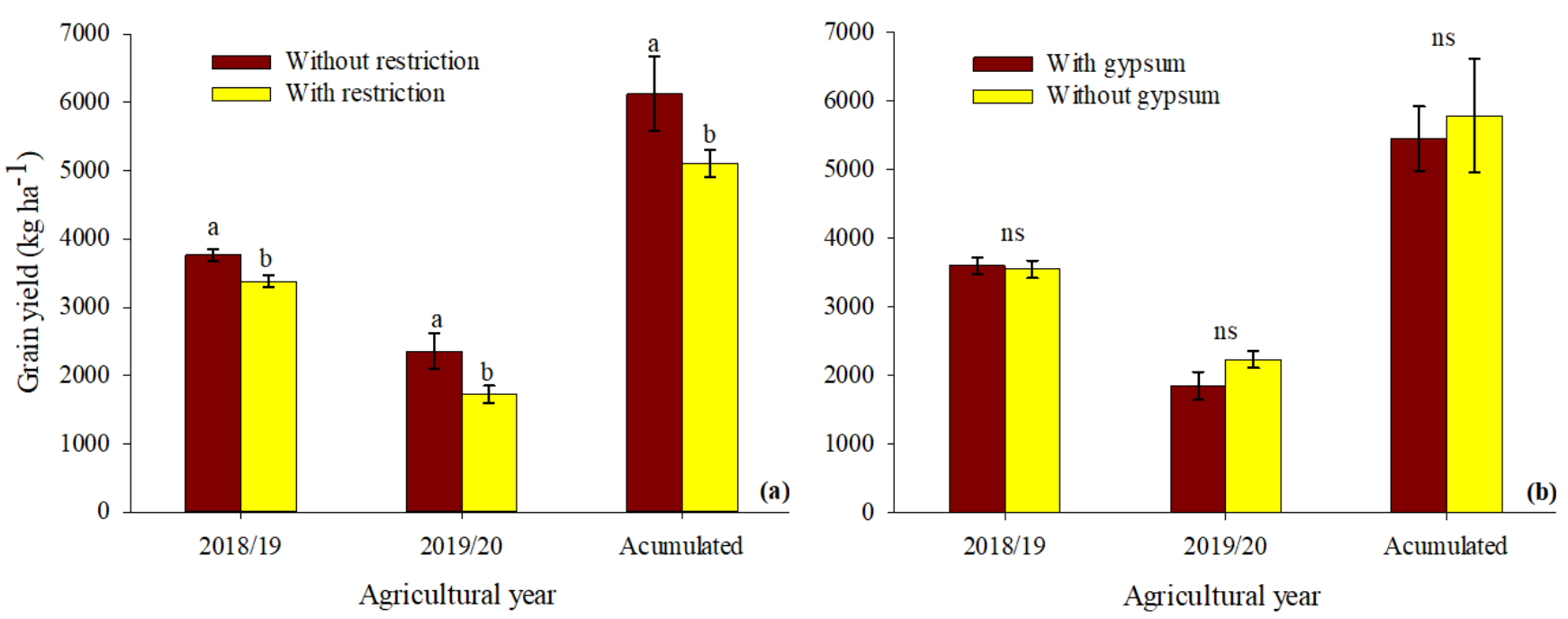

Figure 4. Soybean yield according to the soil water condition (a) and to gypsum application (b), considering the 2018/19, 2019/20 harvests and the cumulative response. Means followed by the same letter in the agricultural year do not differ $(\mathrm{p}<0.05)$. ns: not significant. Vertical lines represent the standard error of the mean.

Differently from what was expected, agricultural gypsum did not influence soybean yield, not even in the condition of water restriction. The major hypothesis in this study was that damage to the plant would be minimized by water deficiency, according to studies conducted by Pias et al. (2020) and Tiecher et al. (2018). As reported by the authors, soybean response to agricultural gypsum is more likely in soils showing water deficiency. In such harmful edaphic conditions, the need for greater root expansion, in association with the benefits provided by gypsum along the soil profile, attenuates damage to plants $[3,13,14]$.

With this regard, several authors emphasize the importance of soil correction in the subsurface for $\mathrm{Al}$ saturation reduction and $\mathrm{Ca}$ content increase. The objective is to improve soil chemical quality along its profile and enable better root development at depth, thus meeting plants' nutritional and water requirements, with positive yield responses $[6,11,12,14]$.

Among the main grain crops, soybeans are the least responsive to gypsum application, especially compared to grasses [12]. According to current bibliographic research, $\mathrm{Al}$ saturation is the main parameter related to decision-making regarding gypsum use. The possible effects of increased yield occur mainly when the values are greater than $10 \%$ in water stress conditions or above $43 \%$ without water stress [12]. Although $\mathrm{Al}$ saturation in this study was above $50 \%$ in the $20-40 \mathrm{~cm}$ layer, soybean yield was not influenced. The lack of response may be related to the high availability of $\mathrm{Ca}$ in the surface layers and its content in the subsurface $\left(>2.0 \mathrm{cmol}_{\mathrm{c}} \mathrm{dm}^{-3}\right)$. Positive responses to gypsum use for soybeans decrease with increasing Ca levels found at depth [12,40]. This effect is related to the greater cation exchange capacity of soybean roots, which gives it a greater ability to absorb bivalent cations than monocots [13]; thus the technical efficiency of gypsum application is 
reduced. The lack of response may also be related to the presence of exchangeable $\mathrm{Ca}$ associated with high SOM content, which can mitigate the harmful effects caused by $\mathrm{Al}$ due to decreased ionic activity in the solution and complexation of the toxic element by organic components [41].

Although gypsum applications increased $\mathrm{S}_{-} \mathrm{SO}_{4}{ }^{2-}$ levels in the soil, the values were still above critical level without its application [9]. This fact indicates the contribution from SOM and biological activity to $\mathrm{S}_{-} \mathrm{SO}_{4}{ }^{2-}$ availability given the $\mathrm{SOM}$ content found (Table 1), which reduces the possibility of gypsum's having responded to provide such nutrient [42]. Also, the moderate acidity level may have contributed to the higher retention of this ion, preventing a more intense leaching process and maintaining adequate levels for the crop [43]. Low agronomic responses to $\mathrm{S}_{-} \mathrm{SO}_{4^{2-}}$ supply are found when its content is above $7.6 \mathrm{mg} \mathrm{dm}^{-3}$ and in subtropical soils that provide a more gradual mineralization rate compared to those in tropical regions [40].

\subsection{Root system characteristics}

There was no significant effect on the root system parameters (Figure 5). Although the water restriction affected soybean yield, the effects of such conditions did not influence root development. Because the soil remains in favorable moisture conditions most of the time, also when there is water restriction (Figure 5a), the roots were not stimulated to increase soil exploration in the subsurface regions. On the other hand, the lack of response to gypsum use may be related to favorable Ca content in the subsurface $(20-40 \mathrm{~cm})$ without applying the conditioner. Thus, Ca was not a limiting factor to root or crop development [43].

Some studies have shown contrasting results of root development given the soil chemical conditions. Greater root development in the subsurface can be observed with gypsum use without effects on yield [44], as well as stimuli caused by the presence of $\mathrm{H}^{+}$ in root growth in acidic soils where $\mathrm{Al}$ undergoes complexation by organic acids [45].

The results obtained in this study did not show any associated effects between agricultural gypsum application and water restriction. Water restriction alone restricted soybean yield, whereas gypsum resulted in the improvement in some of the soil chemical attributes. On the other hand, none of the factors evaluated changed root growth up to the $40 \mathrm{~cm}$ layer. Based on these results, it is believed that agricultural gypsum application in highly buffered soils with high SOM content requires greater attention. Another aspect to which researchers should pay heed is the gypsum rate applied to soils in southern Brazil since they show higher acidity buffering than that observed in soils in the country's central region. According to Tiecher et al. (2018), the maximum economic efficiency for gypsum remains between rates of 2 to $3 \mathrm{Mg} \mathrm{ha}^{-1}$ for crops. However, those studies were developed in Oxisols, where, in chemical terms, acidity buffering occurs predominantly from the clay fraction, unlike soils in high altitude regions, where SOM performs this function more prominently, providing high buffering capacity [46]. 


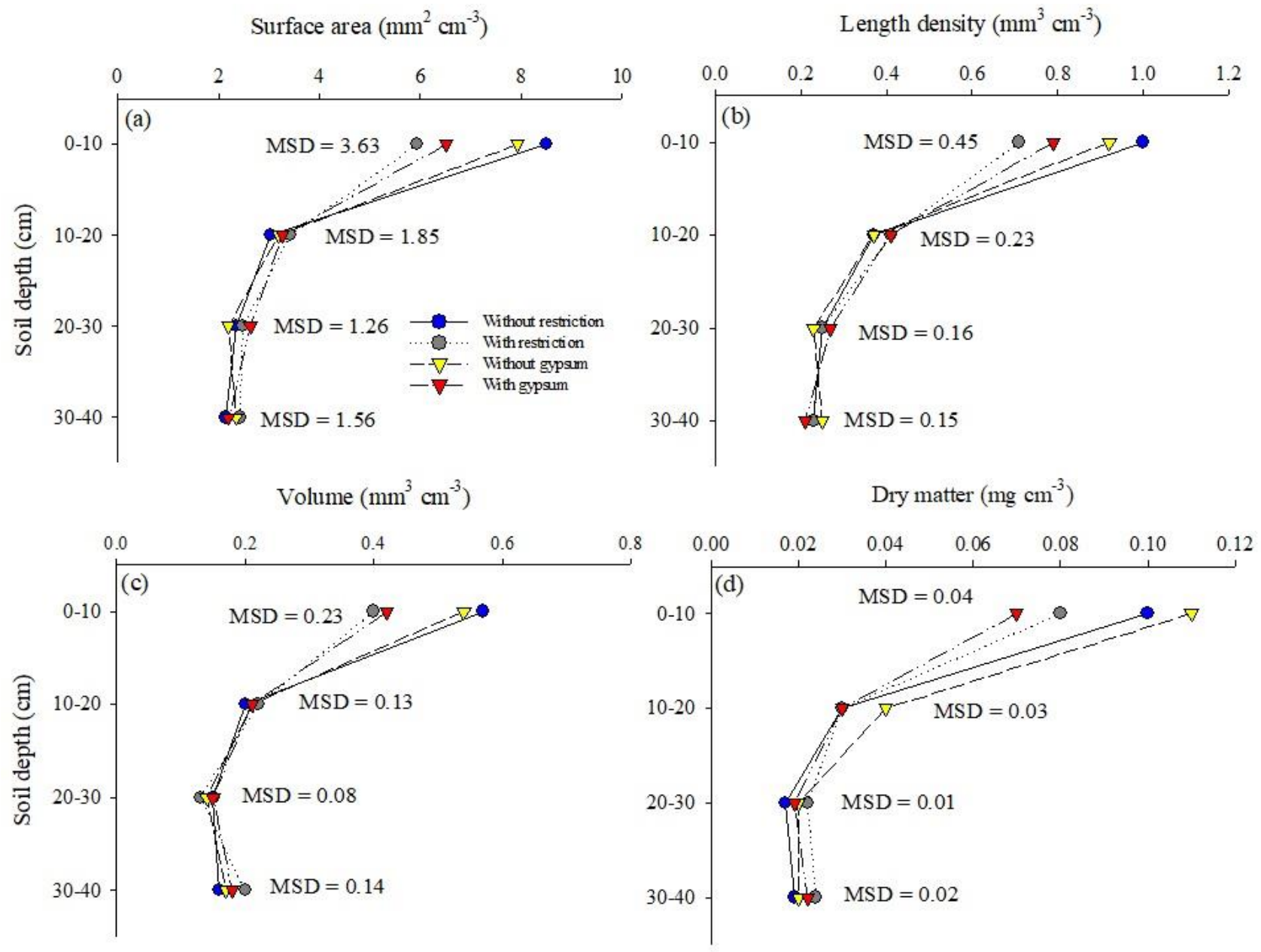

Figure 5. Influence of water conditions and agricultural gypsum management on the root surface area (a), length density (b), root volume (c), and dry root mass (d) in four layers of a Cambisol evaluated in the 2018/2019 harvest. msd: minimum significant difference.

\section{Conclusions}

Agricultural gypsum did not influence root characteristics or soybean yield in water restriction, showing lower productivity under such condition.

Gypsum use promoted chemical changes, such as an increase in calcium, sulfate, and phosphorus in the soil, and a reduction in aluminum content and saturation in CECeffective, without agronomic effects.

\section{Acknowledgments}

Thanks to Coordination for the Improvement of Higher Education Personnel (CAPES) for granting the scholarship to the first author and to UDESC for the facilities to conduct the experiments and for the knowledge.

\section{References}

[1] Wijewardana, C.; Alsajri, F.A.; Irby, J.T.; Krutz, L.J.; Gilden, B.R.; Henry, W.B.; Reddy, K.R. Water Deficit E ff ects on Soybean Root Morphology. Agronomy 2019, 1-15.

[2] Matusso, J.M.M.; Mugwe, J.N.; Mucheru-Muna, M. Effect of different maize and soybean intercropping patterns on yields, light interception and leaf area index in Embu West ang Tigania East sub counties. Acad. Res. J. Agric. Sci. Res. 2014, 2 (2), 6-21. 
[3] Battisti, R.; Sentelhas, P.C. Improvement of soybean resilience to drought through deep root system in Brazil. Agron. J. 2017, 109, 1612-1622, doi:10.2134/agronj2017.01.0023.

[4] Ferrari, E.; Paz, A.; Carvalho, A. Déficit Hídrico No Metabolismo Da Soja Em Semeaduras Antecipadas No Mato Grosso Water Deficit on the Soybean Metabolism in Early Sowings. Nativa 2015, 3, 67-77.

[5] Deus, A.C.F.; Büll, L.T.; Guppy, C.N.; Santos, S. de M.C.; Moreira, L.L.Q. Effects of lime and steel slag application on soil fertility and soybean yield under a no till-system. Soil Tillage Res. 2020, 196, 104422, doi:10.1016/j.still.2019.104422.

[6] Dalla Nora, D.; Amado, T.J.C.; Nicoloso, R. da S.; Gruhn, E.M. Modern high-yielding maize, wheat and soybean cultivars in response to gypsum and lime application on no-till oxisol. Rev. Bras. Cienc. do Solo 2017, 41, doi:10.1590/18069657rbcs20160504.

[7] Caires, E.F.; Zardo Filho, R.; Barth, G.; Joris, H.A.W. Optimizing Nitrogen Use Efficiency for No-Till Corn Production by Improving Root Growth and Capturing NO3-N in Subsoil. Pedosphere 2016, 26, 474-485, doi:10.1016/S1002-0160(15)60058-3.

[8] Ernani, P.R. Química do Solo e Disponibilidade de Nutrientes; 2nd ed.; Lages, SC, 2016; ISBN 9788590844013.

[9] CQFS-RS/SC Manual de calagem e adubação para os estados do Rio Grande do Sul e Santa Catarina; Silva, Leandro Souza Da; Gatiboni, Luciano Colpo; Anghinoni, Ibanor; Sousa, R.O. de, Ed.; 11th ed.; 2016: Porto Alegre, 2016; ISBN 978-85-66301-80-9.

[10] Zoca, S.M.; Penn, C. An Important Tool With No Instruction Manual: A Review of Gypsum Use in Agriculture. Adv. Agron. 2017, 144, 1-44, doi:10.1016/bs.agron.2017.03.001.

[11] Tiecher, T.; Pias, O.H. de C.; Bayer, C.; Martins, A.P.; Denardin, L.G. de O.; Anghinoni, I. Crop response to gypsum application to subtropical soils under no-till in Brazil: A systematic review. Rev. Bras. Cienc. do Solo 2018, 42, 1-17, doi:10.1590/18069657rbcs20170025.

[12] Pias, O.H. de C.; Tiecher, T.; Cherubin, M.R.; Silva, A.G.B.; Bayer, C. Does gypsum increase crop grain yield on no-tilled acid soils? A meta-analysis. Agron. J. 2020, 112, 675-692, doi:10.1002/agj2.20125.

[13] Pauletti, V.; Pierri, L. de; Ranzan, T.; Barth, G.; Motta, A.C.V. Efeito em longo prazo da aplicação de gesso e calcário no sistema de plantio direto. Rev. Bras. Ciência do Solo 2014, 38, 141-149, doi:10.1590/S0100-06832014000200014.

[14] Zandoná, R.R.; Beutler, A.N.; Burg, G.M.; Barreto, C.F.; Schmidt, M.R. Gesso e calcário aumentam a produtividade e amenizam o efeito do défcit hídrico em milho e soja. Pesqui. Agropecu. Trop. 2015, 45, 128-137, doi:10.1590/1983-40632015v4530301.

[15] Alvares, C.A.; Stape, J.L.; Sentelhas, P.C.; De Moraes Gonçalves, J.L.; Sparovek, G. Köppen's climate classification map for Brazil. Meteorol. Zeitschrift 2014, 22, 711-728, doi:10.1127/0941-2948/2013/0507.

[16] Santos, H.G. dos; Jacomine, P.K.T.; Anjos, L.H.C. dos; Oliveira, V.Á. de; Lumbreras, J.F.; Coelho, M.R.; Almeida, J.A. de; Araújo Filho, J.C. de; Oliveira, J.B. de; Cunha, T.J.F. Sistema Brasileiro de Classificação de Solos; 5th ed.; EMBRAPA: Brasília-DF, 2018; ISBN 978-85-7035-800-4.

[17] WRB/FAO World reference base for soil resources 2014, update 2015. International soil classification system for naming soils and creating legends for soil maps.; 106th ed.; 2015: Rome, 2015; ISBN 9789251083697.

[18] Sousa, D.M.G.; Lobato, E. Cerrado: Correção do solo e adubação; 2nd ed.; Brasília-DF, 2004;

[19] Tedesco, M.J.; Gianello, C.; Bissani, C.A.; Bohnen, H.; Volkweiss, S.J. Análise de solo, planta e outros materiais; 2nd ed.; 1995: Porto Alegre, 1995;

[20] Murphy, J.; Riley, J.P. A modified single solution method for the determination of phosphate en natural water. Anal Chim. Acta. $1962,27,31-36$.

[21] Toledo, J. dos S.; Kaminski, J.; Santanna, M.A.; Rheinheimer, D. dos S. Tampão Santa Maria (TSM) como Alternativa ao Tampão SMP para Medição da Acidez Potencial de Solos Ácidos. Rev. Bras. Cienc. do Solo 2012, 36, 427-435, doi:10.1590/S010006832012000200012.

[22] Costa, A. da; Albuquerque, J.A.; Almeida, J.A. de; Costa, A. da; Luciano, R.V. Pedotransfer functions to estimate retention and availability of water in soils of the state of Santa Catarina, Brazil. Rev. Bras. Ciência do Solo 2013, 37, 889-910, doi:10.1590/s010006832013000400007.

[23] Ferreira, D.F. Sisvar: a computer statistical analysis system. Ciência e Agrotecnologia 2011, 35, 1039-1042, doi:10.1590/s141370542011000600001.

[24] Bortolini, D.; Albuquerque, J.A. Estimation of the Retention and Availability of Water in Soils of the State of Santa Catarina. Rev. Bras. Ciência do Solo 2018, 42, 1-13, doi:10.1590/18069657rbcs20170250.

[25] Reichert, J.M.; Albuquerque, J.A.; Kaiser, D.R.; Reinert, D.J.; Urach, F.L.; Carlesso, R. Estimation of water retention and availability in soils of Rio Grande do Sul. Rev. Bras. Cienc. do Solo 2009, 33, 1547-1560, doi:10.1590/s0100-06832009000600004.

[26] Bottinelli, N.; Angers, D.A.; Hallaire, V.; Michot, D.; Le Guillou, C.; Cluzeau, D.; Heddadj, D.; Menasseri-Aubry, S. Tillage and fertilization practices affect soil aggregate stability in a Humic Cambisol of Northwest France. Soil Tillage Res. 2017, 170, 14-17, doi:10.1016/j.still.2017.02.008.

[27] Reichert, J.M.; Albuquerque, J.A.; Solano Peraza, J.E.; da Costa, A. Estimating water retention and availability in cultivated soils of southern Brazil. Geoderma Reg. 2020, 21, e00277, doi:10.1016/j.geodrs.2020.e00277.

[28] Embrapa Tecnologias de produção de soja - Região central do Brasil 2012 e 2013. Sistemas de Produção, 15.; 1st ed.; Londrina, 2011; ISBN 1677-8499. 
[29] Crusciol, C.A.C.; Artigiani, A.C.C.A.; Arf, O.; Carmeis Filho, A.C.A.; Soratto, R.P.; Nascente, A.S.; Alvarez, R.C.F. Soil fertility, plant nutrition, and grain yield of upland rice affected by surface application of lime, silicate, and phosphogypsum in a tropical no-till system. Catena 2016, 137, 87-99, doi:10.1016/j.catena.2015.09.009.

[30] Costa, C.H.M. da; Crusciol, C.A.C. Long-term effects of lime and phosphogypsum application on tropical no-till soybean-oatsorghum rotation and soil chemical properties. Eur. J. Agron. 2016, 74, 119-132, doi:10.1016/j.eja.2015.12.001.

[31] Rheinheimer, D. dos S.; Tiecher, T.; Gonzatto, R.; Santanna, M.A.; Brunetto, G.; da Silva, L.S. Long-term effect of surface and incorporated liming in the conversion of natural grassland to no-till system for grain production in a highly acidic sandy-loam Ultisol from South Brazilian Campos. Soil Tillage Res. 2018, 180, 222-231, doi:10.1016/j.still.2018.03.014.

[32] Geelhoed, J.S.; Hiemstra, T.; Van Riemsdijk, W.H. Phosphate and sulfate adsorption on goethite: Single anion and competitive adsorption. Geochim. Cosmochim. Acta 1997, 61, 2389-2396, doi:10.1016/S0016-7037(97)00096-3.

[33] Bortoluzzi, E.C.; Parize, G.L.; Korchagin, J.; Silva, V.R. da; Rheinheimer, D. dos S.; Kaminski, J. Soybean root growth and crop yield in reponse to liming at the beginning of a no-tillage system. Rev. Bras. Ciência do Solo 2014, 38, 262-271, doi:10.1590/s010006832014000100026.

[34] Araújo, L.G.; de Figueiredo, C.C.; de Sousa, D.M.G.; Nunes, R. de S.; Rein, T.A. Influence of gypsum application on sugarcane yield and soil chemical properties in the brazilian Cerrado. Aust. J. Crop Sci. 2016, 10, 1557-1563, doi:10.21475/ajcs.2016.10.11.PNE156.

[35] Almeida, J.A. de; Silva, T.P. da; Cunha, G.O. de M.; Spido, D.R.; Silva, F. dos S.T. Atributos químicos, físicos e mineralógicos de solos derivados de rochas sedimentares do Planalto de Lages-SC, Brasil. Rev. Bras. Ciencias Agrar. 2019, 14, 1-12, doi:10.5039/agraria.v14i3a6576.

[36] Portela, E.; Monteiro, F.; Fonseca, M.; Abreu, M.M. Effect of soil mineralogy on potassium fixation in soils developed on different parent material. Geoderma 2019, 343, 226-234, doi:10.1016/j.geoderma.2019.02.040.

[37] CONAB, C.N. de A. Acompanhamento da safra brasileira: Graõs; 7th ed.; Brasilia, 2020; Vol. 7; ISBN $2318-6852$.

[38] Gava, R.; Frizzone, J.A.; Snyder, R.L.; Jose, J.V.; Junior, E.F.F.; Perboni, A. Estresse hídrico em diferentes fases da cultura da soja. Rev. Bras. Agric. Irrig. 2015, 9, 349-359, doi:10.7127/rbai.v9n600368.

[39] El-Mageed, T.A.A.; El-Sherif, A.M.A.; Ali, M.M.; El-Wahed, M.H.A. Combined effect of deficit irrigation and potassium fertilizer on physiological response, plant water status and yield of soybean in calcareous soil. Arch. Agron. Soil Sci. 2016, 63, 827-840, doi:10.1080/03650340.2016.1240363.

[40] Fontoura, S.M.V.; Pias, O.H. de C.; Tiecher, T.; Cherubin, M.R.; Moraes, R.P. de; Bayer, C. Effect of gypsum rates and lime with different reactivity on soil acidity and crop grain yields in a subtropical Oxisol under no-tillage. Soil Tillage Res. 2019, 193, 27-41, doi:10.1016/j.still.2019.05.005.

[41] Miotto, A.; Tiecher, T.; Kaminski, J.; Brunetto, G.; De Conti, L.; Tiecher, T.L.; Martins, A.P.; Rheinheimer dos Santos, D. Soil acidity and aluminum speciation affected by liming in the conversion of a natural pasture from the Brazilian Campos Biome into no-tillage system for grain production. Arch. Agron. Soil Sci. 2019, 66, 138-151, doi:10.1080/03650340.2019.1605164.

[42] Fois, D.A.F.; Lana, M. do C.; Vera, L.R.Q.; Álvarez, J.W.R.; Rojas, A.C.L.; Tiecher, T. Efeito do gesso agrícola na disponibilidade de enxofre e no rendimento da soja e milho safrinha. Rev. Cultiv. o saber 2017, 10, 314-326.

[43] Pias, O.H.D.C.; Tiecher, T.; Cherubin, M.R.; Mazurana, M.; Bayer, C. Crop yield responses to sulfur fertilization in brazilian notill soils: A systematic review. Rev. Bras. Cienc. do Solo 2019, 43, 1-21, doi:10.1590/18069657rbcs20180078.

[44] Santos, E.L. dos; Debiasi, H.; Franchini, J.C.; Vieira, M.J.; Junior, A.A.B. Chiseling and gypsum application affecting soil physical attributes, root growth and soybean yield. Rev. Cienc. Agron. 2019, 50, 536-542, doi:10.5935/1806-6690.20190063.

[45] Caires, E.F.; Barth, G.; Garbuio, F.J.; Churka, S. Soil acidity, liming and soybean performance under no-till. Sci. Agric. 2008, 65, 532-540.

[46] Almeida, J.A. de; Ernani, P.R.; Maçaneiro, K.C. Recomendação alternativa de calcário para solos altamente tamponados do extremo sul do Brasil. Ciência Rural 1999, 29, 651-656, doi:10.1590/s0103-84781999000400014. 